\title{
PROTEINS IN FLUIDS FROM DIFFERENT SEGMENTS OF THE RAT EPIDIDYMIS
}

\author{
AARNE I. KOSKIMIES AND MARTTI KORMANO \\ Department of Anatomy, University of Helsinki, Finland
}

(Received 21st October 1974)

The fluid transporting spermatozoa out of the testis through the epididymis is known to undergo many changes. About $50 \%$ of the fluid secreted by the seminiferous tubules is reabsorbed by the first part of the epididymal duct system (Crabo \& Gustafsson, 1964; Levine \& Marsh, 1971). Between the caput epididymidis and the ductus deferens, a further $50 \%$ of the remaining fluid is reabsorbed.

Seminiferous tubule fluid and rete testis fluid contain several protein fractions not seen in the serum, as has been shown by polyacrylamide gel electrophoresis (Kormano, Koskimies \& Hunter, 1971; Koskimies \& Kormano, 1973). The fate and significance of most of these proteins is unknown. Recently, it has been shown electrophoretically that bovine epididymal plasma from the cauda region contains at least three proteins not detected in the rete testis fluid or serum (Amann, Killian \& Benton, 1973).

In the present report, the protein pattern of rat epididymal fluid was compared with that of rete testis fluid (RTF) and ductus deferens fluid (DDF) using a step-gradient polyacrylamide gel electrophoresis. Fluid samples were collected from the caput, corpus and cauda regions and from the ductus deferens by a micropuncture technique (Tuck, Setchell, Waites \& Young, 1970). The RTF was collected $24 \mathrm{hr}$ after ligation of the efferent ducts. The proteins were separated electrophoretically in an Ortec high-resolution electrophoresis unit. The initial acrylamide concentration in $\mathrm{g} / 100 \mathrm{ml}$ was 4.5 , rising in steps to 6 , 8 and 12. The separating gel buffer was 0.75 M-tris-sulphate, $\mathrm{pH} 9 \cdot 0$, and the tank buffer was $0.065 \mathrm{M}$-tris-borate buffer, $\mathrm{pH} \mathrm{9 \cdot 0.} \mathrm{A} \mathrm{more} \mathrm{detailed} \mathrm{description}$ of the technique has been given earlier (Koskimies \& Kormano, 1973).

A diagrammatic summary of the protein patterns is seen in Text-fig. 1. The total number of protein bands found in all epididymal fluids was less than in RTF. Fluids from the caput and corpus regions were remarkably similar. Likewise, the general protein patterns of cauda fluid and DDF were almost identical, but there were greater numbers of protein bands in these two fluids due to the presence of serum proteins with an intermediate mobility. The albumin band (No. 27 in Text-fig. 1) was always weaker in the epididymal fluids than in RTF or blood serum (Text-fig. 2). The presence of five heavily stained prealbumin bands, two of which were not found in RTF or serum, was typical of the epididymal fluid proteins. A third band specific to the epididymal fluids had a low electrophoretic mobility (Text-fig. 1, se). An interesting finding was the absence of several specific RTF protein bands in the epididymal fluids 


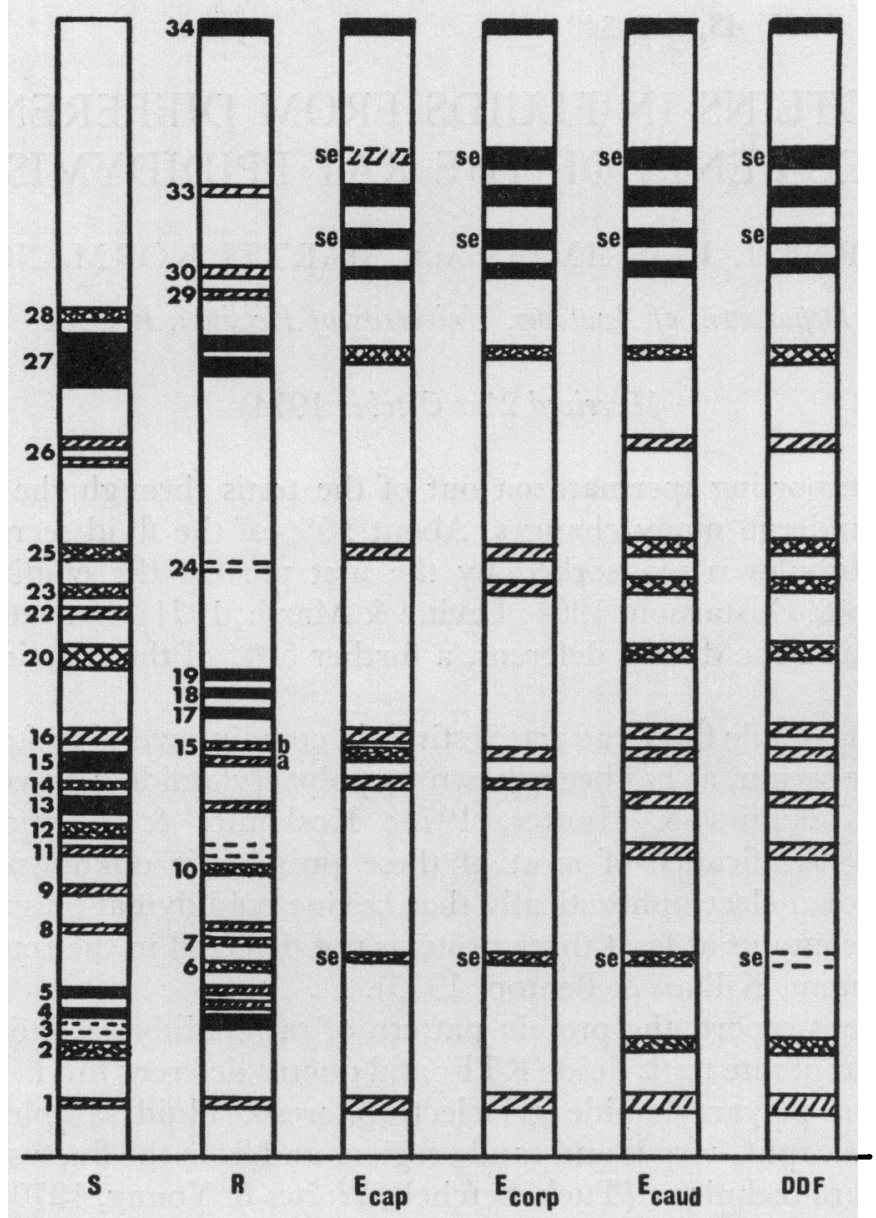

TExT-FIG. 1. Diagram of the protein bands of rat body fluids separated with step-gradient acrylamide gel electrophoresis. $\mathbf{S}=$ serum; $\mathbf{R}=$ rete testis fluid; $\mathbf{E}=$ epididymal fluids from caput (cap), corpus (corp) and from cauda (caud); DDF = ductus deferens fluid; se = protein bands specific to epididymal duct and ductus deferens fluids (not seen in rete testis fluid or serum).

(Nos 6, 7, 10, 15b, 17, 18, 19, 24 and 29: see Koskimies \& Kormano, 1973). The distinct triplet band with an intermediate mobility (Nos 17, 18 and 19), typical of RTF, was totally lacking in fluid from the caput epididymidis. The specific prealbumin bands 30,33 and 34 , also typical of RTF, were also found in the epididymal fluids.

The ultrastructure of the cells of the efferent ducts (Burgos, 1957; Ladman \& Young, 1968) and the caput epididymidis, especially the initial segment (Hamilton, 1972), is typical of cells with resorptive capacity. Most of the proteins secreted into the RTF seem to be reabsorbed in these two first segments of the extratesticular duct system. With the techniques used, it was impossible to obtain reliably uncontaminated samples of intraluminal fluid from the initial segment itself. Most of the protein absorption, however, is likely to occur in the heavily vascularized initial segment and not in the efferent ducts. 


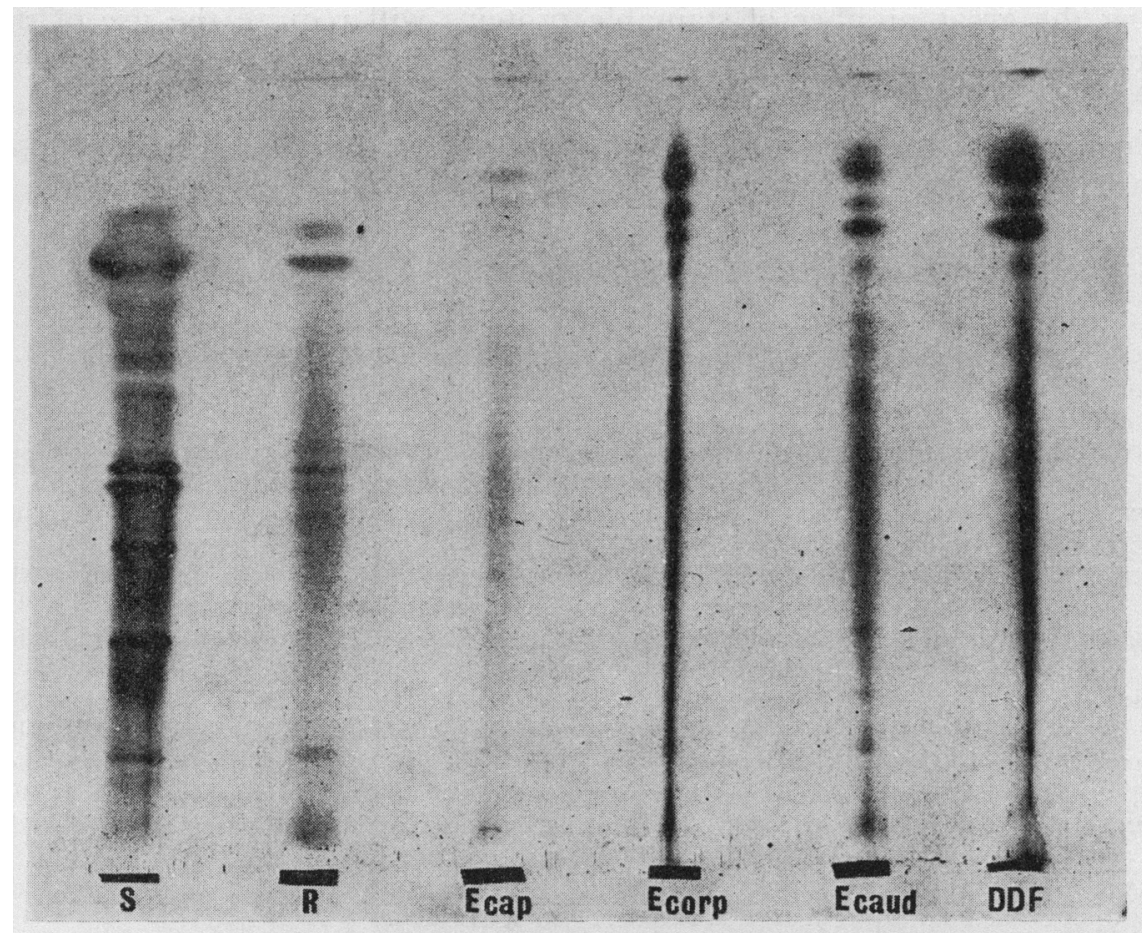

TExr-FIG. 2. Electrophoretic protein pattern of rat serum, rete testis fluid, epididymal fluids and ductus deferens fluid. The abbreviations are the same as in Text-fig. 1 .

Recently, a specific androgen-binding protein (ABP) with high affinity for dihydrotestosterone and testosterone, has been demonstrated in RTF (French \& Ritzen, 1973a), and seems to be an extracellular transport protein. It is produced in the rat testis, secreted into testicular fluid and carried into the epididymis (French \& Ritzen, 1973b; Hansson \& co-authors, 1974). French \& Ritzen (1973b) showed that a major portion of the ABP either loses its binding activity or disappears from the soluble supernatant because of absorption from the lumen and uptake by an insoluble organelle of epididymal cells. The total concentration of ABP in RTF is so small that it is unlikely that the technique used here would be able to demonstrate it as a separate band. The same applies to the proposed substance regulating the intensity of spermatogenesis, the socalled 'inhibin' (Setchell \& Sirinathsinghji, 1972). Such a protein, secreted into RTF, could be reabsorbed from the caput epididymidis into the blood.

The present study clearly shows that the first part of the excurrent duct system selectively absorbs some of the proteins secreted by the seminiferous tubules. The finding that new bands appeared in the epididymal fluid is in agreement with the results of Amann et al. (1973) who found that certain proteins in cauda fluid are distinct from proteins detected in RTF or serum. Thus, some components are of epididymal origin and can be regarded as evidence for the secretion of protein by the epididymis. Further information regarding the location and fate of the known active proteins (ABP and inhibin) 
among the great number of stainable proteins will require the use of more sensitive techniques.

This investigation received financial support from the World Health Organization.

\section{REFERENCES}

Amann, R. P., Killian, G. J. \& Benton, A. W. (1973) Differences in the electrophoretic characteristics of bovine rete testis fluid and plasma from the cauda epididymidis. F. Reprod. Fert. 35, 321-330.

Burgos, M. H. (1957) Fine structure of the efferent ducts of the hamster testis. Anat. Rec. 127, 401, Abstr.

Crabo, B. \& Gustafsson, B. (1964) Distribution of sodium and potassium and its relation to sperm concentration in the epididymal plasma of the bull. J. Reprod. Fert. 7, 337-345.

FrENCH, F. S. \& RITZEN, E. M. (1973a) Androgen-binding protein in efferent duct fluid of rat testis. J. Reprod. Fert. 32, 479-483.

French, F. S. \& Ritzen, E. M. (1973b) High affinity androgen binding protein in rat testis: evidence for secretion in efferent duct fluid and absorption by epididymis. Endocrinology, 93, 88-95.

Hamilton, D. W. (1972) The mammalian epididymis. In Reproductive Biology, pp. 268-337. Eds. H. Balin and S. Glasser. Excerpta Medica, Amsterdam.

Hansson, V., Mclean, W. S., Smith, A. A., Tindali, D. J., Weddington, S. C., Nayfeh, S. N., French, F. S. \& RitzeN, E. M. (1974) Androgen receptors in rat testis. Steroids, 23, 823-832.

Kormano, M., Koskimies, A. I. \& Hunter, R. L. (1971) The presence of specific proteins, in the absence of many serum proteins in the rat seminiferous tubule fluid. Experientia, 27, 1461-1463.

Koskimies, A. I. \& Kormano, M. (1973) The proteins in fluids from the seminiferous tubules and rete testis of the rat. J. Reprod. Fert. 34, 433-444.

Ladman, A. J. \& Young, W. G. (1968) An electron microscopic study of the ductuli efferentes and rete testis of the guinea pig. F. biophys. biochem. Cytol. 4, 219-226.

LeVine, N. \& Marsh, D. J. (1971) Micropuncture studies of the electrochemical aspects of fluid and electrolyte transport in individual seminiferous tubules, the epididymis and the vas deferens in rats. F. Physiol., Lond. 213, 557-570.

Setchell, B. P. \& Sirinathinghi, D. J. (1972) Antigonadotrophic activity in rete testis fluid, a possible inhibin. F. Endocr. 53, 1x-lxi, Abstr.

Tuck, R. R., Setcheld, B. P., Wartes, G. M. H. \& Young, J. A. (1970) The composition of fluid collected by micropuncture and catheterization from the seminiferous tubules and rete testis of rats. Pflügers Arch. ges. Physiol. 318, 225-243. 